\title{
Primacy of the Image. From Einbildungskraft to Mythological Unconscious
}

\author{
Aleš Vrbata \\ Universidade Estadual de Feira de Santana, Bahia, BR
}

VRBATA, A.: Primacy of the Image. From Einbildungskraft to Mythological Unconscious.

Philosophica Critica, vol. 3, 2017, no. 2, ISSN 1339-8970, pp. 35-52.

In more than two-thousand-years lasting western philosophical tradition the role of the image and its epistemological status were quite small and irrelevant. It was during Renaissance and within 18th-century philosophy (Kant's Einbildungskraft) when situation started to change and image was progressively freed from the tutelage of reason. Kant's Einbildungskraft introduced new field within human mind transcendent to human subject and later there was a large conceptual field of the unconscious with its implications in other areas. Since the early 20th century epistemological status of image changed even more. This article attempts not only to review this development but also to examine revolutionization of the epistemological status of "imagined reality", especially new concepts arising from such perspective in the course of last fifty years.

Key words: Reality - Image - Unconscious - Myth - Psyche

\section{Ego's Philosophizing: \\ Philosophy Unaware of its Backstage Imagery}

His [Jung's] formulation of psychic image as a bridge between ideas and things comes after an extended discussion of the Medieval debate between nominalism and realism. Jung formulates his view of imaging as a mediating third position, esse in anima, between what today would be called deconstruction and universalism. Psychic images point beyond themselves to both the "historical particulars" of the world around us and the "essences" and "universals" of the mind and metaphysics. Psychic images signify something that consciousness and its narcissism cannot quite grasp (...)

(Kugler 2008, 89) 
Imagery played a key role in the history of western thought and philosophy. It seems that thinking and imaging are closely interconnected, but for the most part of western philosophical tradition thinking, thoughts and ideas enjoyed much higher epistemological status than image, imaging, and human power to imagine. Such tutelage of reason over imaging is something that certainly reflects certain stereotyped way of viewing both human nature and the world. This article pretends to elucidate the way how imaging freed itself from such tutelage and became, mainly thanks to psychoanalysis but also thanks to philosophical thinking about the unconscious, the central issue in contemporary western thought.

Western philosophy had a particularly hard to time to move beyond idea/ratio and to recognize the power of imaging as the place where the meaning can be found but there were also those who suspected the importance of "dark" or "nebulous" perceptions or ideas which later led to the idea of "the unconscious". In this respect, scientific ideal of objective and positive knowledge so dear to the Enlightenment had to make significant concessions to the romantic thought. The same can be applied to Sigmund Freud who, in 1870s, started his career as a representative of Newton-Cartesian, mechanistic-materialist scientific paradigm. This article emphasizes several historical turning-points representing the shift from the Cartesian paradigm (idea) to the Romantic paradigm (image). Probably the most underscored of them is the breakup between Freud (Reality Principle) and Jung (Fantasy Principle), but the move from the primacy of Cartesian (clear and distinctive) idea to the primacy of Romantic (Goethean, Schellingian, Jungian, Hillmanian, unclear, multivocal, symbolic, unconscious) image was a much more complex process whose description would require much more space.

In the first part of this paper, I am going to describe the development of ideaimage relation within western philosophical tradition considering Plato's "theory of reproduction" (image considered as a mere "reproduction" of the original and ontologically "real" Idea, $\varepsilon\llcorner\delta o \varsigma$ ) as a starting point and pointing at Kant's concept of Einbildungskraft and Jung's Wandlungen und Symbole der Libido (1912) as the most important phases of dethroning of Newton-Cartesian paradigm and, by extension, Enlightenment philosophy. In the second part, I venture beyond classical Jungian discourse into post-Jungian discourse as it was introduced by James Hillman (Hillmanian rendering of Jung proceeding from Jung's thesis of image as a primary resource of human knowledge) where human psyche is conceived as lacking structure whatsoever and producing so-called "imaginal reality". In the third part, I am elucidating post-Jungian vision of psyche as stemming from unconscious and unstructured field of plurality of complexes whose preeminent attribute is its mythological aspect (Erich Neumann, Michael Vannoy Adams). Such a development exemplifies a gradual leaving behind not only of NewtonCartesian paradigm or Enlightenment philosophy assumptions but also starting points of Freudian psychoanalysts. 
According to Kugler epistemological status of image belonged to the most important philosophical questions already in ancient philosophy: "Perhaps nothing in Western thought has appeared more necessary, and yet more problematic to our understanding of mental imagining, than the need for some kind of universal (...). Western thought has struggled with the question of whether or not there are universal principles upon which to found our concept of human nature. Are there particularly human attributes of the mind, such as reality, truth, self, good, reason, being, or image?" (Kugler 2008, 77-78). The first theory of image appeared in Plato's myth of cave in which he juxtaposed eternal $a$ priori ideas and specific material object in space-temporal reality. Plato described relation between both, using metaphors like "painting" or "figuring". Even though so-called material reality is subject to time and perishes whereas a priori ideal lasts, Plato considered material reality as ontologically inferior. For Plato a priori ideas are in extra-psychic images, i.e. they are metaphysical entities. Simultaneously, images of everyday life are copies derived from eternal ideas. Ontologically they are inferior to material objects, but at the same time have a great value: they can conserve human experience and wisdom, contact with eternal ideas. They could invoke illusions as well. In such a case they work as a drug.

Aristotle elaborated a different theory of image which was, ironically, also a reproduction theory. He does not localize image in the metaphysical or psychological sphere. For him image is a mental intermediary between senses and reason, it is a bridge between the inner and the outer world.

Reproduction theory of image did not change during Middle Ages. Medieval thinkers followed reproductive view of imaging in the same way as Augustine, Bonaventure or Thomas Aquinas. At that time image was always located between primordial dualities such as inner-outer, mind-body or reason-sensation, enabled connection between metaphysical order and spatio-temporal reality.

Situation started to change not until renaissance. Paracelsus, Ficino, Bruno, alchemists and hermetic philosophers were the first who revised radically the above mentioned concept of the image. For them, power of imaging is located within human condition. In Bruno imaging precedes reason; it is a creative force inherent with human being and is neither divine nor metaphysical or material. Something similar took place also in alchemy where alchemists' attention passed from metaphysics to psychology. But a definitive rupture with medieval scholastics was brought about only by modern philosophy. In Meditationes (1642) Descartes divided the world into res extensa (objective matter) and res cogitans (knowing subject). According to him the source of the meaning is found in human subject, i.e. human subject is given priority to the objective being or divine. Descartes located creativity, meaning and truth within human subject, but, ironically, still believed in imaging as reproductive activity. 
Dramatic shift is represented by David Hume. For him, without leaning against metaphysical scaffolding, human reason becomes arbitrary fictionalism or solipsism. Hume suggested psychological thesis which challenged reproductive theory of the image: it says that all human knowledge is derived from association of images-ideas and has no more need to refer to metaphysical transcendent entities. Consequently, for Hume mental image is the only reality, the only truth we can know which, by extension, means no truth. It constituted a big problem because Hume followed correspondence theory of truth, e.g. if there is no correspondence between mental image and transcendent object, we are not able to establish truth. But Hume has no "transcendent reality", his mental images have no metaphysical scaffolding so his "world" is a collection of images and fictions without any metaphysical foundations:

\begin{abstract}
"If we embrace this principle [the primacy of imaging] and condemn all refined reasoning, we run into the most manifest absurdities. If we reject it in favour of these reasonings, we subvert entirely the human understanding. We have therefore, no choice but betwixt a false reason and none at all. For my part, I know what ought to be done in the present case" (Hume 1976, 110).
\end{abstract}

In his ground-breaking work Kritik der Reinen Vernunft (1781) Immanuel Kant stated that the human power of imaging (Einbildungskraft) is a precondition of all knowledge. For him reason and sensation are not reproduced but produced by imaging. Such a radical shift in the theory of knowledge also opened way to the concept of unconscious which was under way at that time. Revolutionary aspect of Einbildungskraft has two points: 1) imaging is both productive and reproductive, 2) Kant's synthetic categories are transcendent to reason, e.g. there is a new ground within human mind: transcendent to the knowing subject. Mental image ceased to be a copy and assumed a completely new role of ultimate origin of meaning and human reality. Kant initiated what Kugler calls "liberation of imaging from the grip of reason" and in the 19th century "a more peaceful rapport between the two [reason and image] begins to be established" (Kugler 2008, 85). Such liberation led to several European movements like New Romanticism in England and France or to German romantic philosophy.

New discoveries on the field of imaging within human subject paralleled the birth of unconscious concept which lurked behind of several German philosophical theories (Leibniz, Wolff, Kant, Platner, Baumgarten) already in the 18th century. In philosophy this theme was so significant that today's philosopher Günter Göde classified this philosophy into three historical-philosophical traditions of unconscious: 1) cognitive unconscious, 2) romantic tradition, 3) tradition developed in opposition to post-Kantian thought.

During the first half of the 19th century first psychologies of unconscious were vaguely conceived (Mesmer, Puységur). Some of them were only nebulously con- 
ceptualized, others anticipated later psychology of unconscious (Carus), and others added to intuitive concept of unconscious mythological imagery (Bachofen) but it was only Freud and Jung who initiated detailed studies of mental imagery. In later 19 th century dreams, fantasies, visions, associations were studied because there was an effort to know how they contribute to the evolution of personality and to psychopathology. For psychology and psychopathology it was a new theme, but in the history of literature and western thought it was something quite common. Jung and Freud approached philosophy and western thought very differently. Freud usually avoided philosophical texts, but Jung constantly entertained western thought. His book Psychological Types (1921) written after the rupture with Freud, at the time when Jung formulated archetype and theory of image, suggested a new view on depth-psychology. Whereas Freud understood images as representatives of instincts, Jung viewed imaging as primary phenomenon like renaissance thinkers, e.g. as an autonomous activity of the psyche. In this respect Jung was inspired by Kant's Kritik der Reinen Vernunft and the thesis according to which reason leans against transcendent (beyond reason) a priori structures (time, space, number and so on). Jung applied some implications of these theses on:

"One could also describe these forms as categories analogous to the logical categories which are always and everywhere present as the basic postulates of reason. Only, in the case of 'forms', we are not dealing with categories reason but categories of the imagination ... The original structural components of the psyche are of no less surprising a uniformity than are those of the body. The archetypes are, so to speak, organs of the prerational psyche. They are eternally inherited forms and ideas which have no specific content. Their specific content only appears in the course of the individual's life, when personal experience is taken up in precisely these forms" (Jung 1973, 517-518).

Even though Kant viewed reason as based on a priori structures that are transcendent to it, in contrast to Jung and Freud he did not have concept of unconscious available. Jung worked with image in a much more sophisticated way. In fact, it was mental image and imagery that turned out to be basis of his concept of unconscious and, consequently, human subject. If Kant postulated a priori structures of human reason, Jung postulated a priori structures of human psyche, that are found in the unconscious and have to do with specifically human activities as mothering, fathering, birth and rebirth, identity, ageing, growing and so on, e.g. archetypes described as "organs of psyche" in the same way as body has its organs. This is a perspective which became particularly useful for Jung's disciples as Erich Neumann, Marie-Louise von Franz and others: 
"The structural elements of the collective unconscious are named by Jung 'archetypes' or 'primordial images'. They are the pictorial forms of instincts, for the unconscious reveals itself to the conscious mind in images which, as in dreams and fantasies, initiate the process of conscious reaction and assimilation. (...) As organs of the psyche's structure the archetypes articulate with one another autonomously, like physical organs, and determine the maturation of the personality in a manner analogous to the biological hormone-components of the physical components" (Neumann 2014, xv-xvi).

According to this perspective unconscious is viewed as a constantly empty psychic "stomach" which requires its food (personal experience) passing through it. Such experience is supposed to be "metabolized" by the unconscious and archetypally structured.

In Jung's thought, psyche produces images spontaneously and autonomously and mediates thus between conscious world (whose center is the ego) and the world of objects:

"The psyche creates reality every day. The only expression I can use for this activity is fantasy ... Fantasy, therefore, seems to me the clearest expression of the specific activity of the psyche. It is, pre-eminently ... [a] creative activity" (Jung 1971, 5152).

This thesis is extremely important for today's post-Jungians, particularly for archetypal school which locates image in the center of its attention. From purely epistemological perspective (mental/psychic) image as conceived by Jung and his disciples is the place where the inner and the outer experiences come together. Thus, image mediates between the outer and the inner and effaces the strict division line between them. It means that the way how humans experience reality results neither from external or metaphysical realm (ideal forms, god) nor from the matter. What is experienced as external has its source in imaging activity of psyche (that part of psyche which is beyond control of the ego's subjectivity).

At the very beginning of the 20th century the image finally ceased to be viewed as copy or copy of copy. The turning point of such a shift can be considered Jung's Wandlungen und Symbole der Libido (1912) (in English Symbols of Transformation, 1956). This work is dedicated to the interpretation of dreams and fantasies of Miss Frank Miller, an American woman Jung did not know but whose imagery encountered in Théodore Flournoy. Here psychic imagery reveals its universal mythological aspect, the aspect of mental imagery I am going to turn to in the next part. 


\section{Primacy of the Image: Reality Principle Overthrown}

There are more differences between Freud and Jung. The point here is not only a mythical image in human psyche but an image in itself. Whereas Jung was convinced about epistemological primacy of mental image (e.g. fantasy), Freud followed "reality principle". As Michael Vannoy Adams - who introduced concept of "fantasy principle" in the psychoanalytic discourse - observed, Freud differentiated between reality and fantasy: reality equated with reason whereas fantasy with illusion. ${ }^{1}$

For Freud fantasizing and daydreaming is the same thing because they are wish-fulfillments and the motives for them are unsatisfied wishes and desires. In Freud, pleasure principle equates fantasy principle. If people cannot satisfy their dreams, wishes, pleasures, they dream, fantasize and the purpose of analysis is to cure patients of such fantasies.

Jungian perspective is different. Jung himself equates soul/psyche with image and imagery: "image is psyche" (Jung 1968, 50) or "every psychic process is an image and 'imagining"' (Jung 1970, 544) or "the psyche consists essentially of images" (Jung 1969, 325). Adams, as one of the prominent representatives of archetypal/imaginal psychology says that psyche constructs and deconstructs reality:

“(...) the psyche, or the images, 'creates' reality (which might imply that the activity of fantasy creates reality ex nihilo), I myself prefer to say that it constructs reality. Thus I emphasize what I call the psychic construction of reality, or the imaginal construction of reality. (...) In addition, I would say that reality is not only constructed but also, as Jacques Derrida might say, deconstructed by the imagination. In this respect, the imaginal deconstruction of reality is just as important as the imaginal deconstruction of it. Non-ego images spontaneously and autonomously manifest in the psyche in order to deconstruct (...) images that the ego-image has previously privileged" (Adams 2004, 5-6).

\footnotetext{
${ }^{1}$ Freud defines the reality principle in contrast (not in contradistinction) to the pleasure principle. The exigencies of reality, Freud says, require the ego "to postpone the obtaining of pleasure altogether". Such an ego, he says, "has become 'reasonable'; it no longer lets itself be governed by the pleasure principle, but obeys the reality principle, which also at bottom seeks to obtain pleasure, but pleasure which is assured through taking account of reality, even though it is pleasure postponed and diminished". As Freud defines ego, it is "reason" - or reason in the service of the reality principle. In short, for the ego to be reasonable is for it to be realistic. Freud declares in no uncertain terms that "a happy person never phantasies, only an unsatisfied one" (Adams 2004, 4).
} 
Jung's emphasis on psyche's capacity to create (construct or de-construct) images is that part of his work on which Hillman based his programmatic dictum of archetypal psychology: "stick to the image" or "first fantasy then reality" (Hillman $1975,23)$. Statements like "we live immediately only in the world of images" (Jung 1969, 328) or that "the world itself exists only so far as we are able to produce an image of it" (Jung 1970, 479) do not make him a solipsist but he believes that image/fantasy mediates our inner and outer experience and thus is far from Freudian view on fantasy, imagery or dreaming. It means that what we generally call reality is not reality at all but imaginal reality. This is also a reason why Jung did not follow Freud and his "reality principle". For Jung the purpose of analysis is not to cure patients from their fantasies but to interpret, understand or experience what is behind specific fantasy of this or that person. For archetypal psychology, correcting of specific fantasy according to reality criterion means losing the significance of fantasy altogether. This is exactly that aspect of Jung's thought that was elaborated by Hillman and his archetypal school. But Hillman differs significantly from Jung because as he says:

“(...) I don't emphasize, or even use, some of Jung's terms, like: self, compensation, opposites, types, psychic energy. You won't find anything about mandalas and wholeness, and I don't refer much to Eastern thought, synchronicity, and the JudeoChristian God-image (...)” (Hillman 1983, 30).

Even the concept of image and imagery is different in Hillman because he and all the archetypal school started being aware of the role of the cultural aspect of unconscious and abandoned the very term "unconscious" in favour of "(unconscious) imagination":

\footnotetext{
“He [Jung] didn't like high culture, and he really didn't like neurotic modern 'unnatural man' and preferred to reflect in terms of tribal people, peasant people. But maybe one of the biggest differences is that I tend to use 'imagination' instead of that word 'unconscious' ... not that there isn't unconsciousness in us all the time ... but I won't use the word as an abstract noun to cover over the cultural implications that are in imagination. Jung takes the unconscious as a field of nature. It still bears traces of Freud's id, Darwinian prehistorical islands or Africa. Besides, the word 'unconscious' is loaded with the subjectivity and has become a psychologism. 'Imagination' connects you at once with a tradition and with aesthetic activity. With language. It refers directly to images which Jung himself says are the main content of the unconscious" (Hillman 1983, 32).
}

Mental images are always related to what is generally called reality but "reality" is a very problematic concept because it is something we are always imagining. That is why some post-Jungians prefer term "imaginal reality": there are as many realities as people/subjects/psyches in the world. Adams uses concepts of "imagi- 
nal reality" as a complementary to "external reality" to explain what he calls "theory of imaginal reality". In other words one "external reality" can relate to various and numerous imaginal realities. Referring to J. H. van den Berg or P. S. Perls, Adams exemplifies such theory of imaginal reality:

"A merchant, looking at the corn-field, will estimate the gain he may derive from handling the sale of the crop, while a couple of lovers, choosing the cornfield as a place in which to withdraw from the world, do not care at all about its monetary value. A painter may grow enthusiastic about its slowly moving harmonies of light and shade (....)" (Adams 2004, 8).

In contrast to Perls who says that external reality is relative to the "interest" of individuals (Perls 1969, 40), Adams argues that it is relative to the fantasies of individuals. As we can see fantasy participates in what we call and perceive as reality, or - using Adams philosophical idea - fantasy constructs and de-constructs reality. Reality is constructed mentally, psychologically, imaginally. This is quite different view than that of Freud.

Looking closer to Freud, Jung and post-Jungians, we can identify big differences between them. For Freud images mean always something different than what they seem to say. It is necessary to decipher them, to disclose their meaning behind the image. For Jung images disguise a latent reality. That is why Freud needed to translate (sexualize) images: into sexual organs. In other words, for Freud unconscious is a highly sexual(ized) one. That is why Adams calls Freudian method of interpreting "genitomorphic". For Jung, there is no reason to think that unconscious discloses meanings of its images: "There is no reason to believe that the unconscious does not say what it means; in sharpest contradiction to Freud, I say that unconscious says what it means" (Adams 2004, 9). Jung does not translate images but defines them because he believes that it has an ability to choose apt image to say what it wants to say. One of the aims of analysis is to define and understand what such images mean and that is why he says that analysis "must stick as close as possible", principle that Rafael Lopez Pedraza and James Hillman elevated to Jungian dictum. But there are images of different nature. This aspect of Jungian or post-Jungian thought have had significant repercussions in different field of its inter-disciplinary application like cultural studies, literary critique (Maud Bodkin, Bettina Knapp, Susan Rowland, Clifton Snider), historiography (Joseph Toynbee, Ruth Meyer), film studies (James Iaccino, Luke Hockley), politics (Lawrence Alschuler, Roberto Gambini, V. W. Odajnyk, Andrew Samuels) or cultural studies (Joseph Henderson, Michael Vannoy Adams, Thomas Singer, Samuel Kimbles).

If Jung initiated questioning Freudian "reality principle", it was James Hillman who brought it to its ultimate consequences. Hillmanian advocacy of the primacy of "the fantasy principle" became so expressive and principled that today we can 
consider it - together with "follow your bliss" (Joseph Cambell) or "stick to the image" (James Hillman) - a programmatic slogan of archetypal post-Jungian tradition. Such trend is closely connected to what Adams calls "post-structural Jungian theory" (Adams 2004, 40-56).

One of the typical features of Hillmanian archetypal theory is that it rejects Jungian structural bi-polar concept of psyche (ego-Self axis plus archetypes or complexes like "persona", "shadow", "anima", "animus" etc.). ${ }^{2}$ Hillman rarely speaks of "Self" and ridicules "ego". In Jung "Self" is "concept of concepts", it is a God with capital G or Yahweh with capital Y. In this respect Jung, in spite of his recognition of almost limitless possibilities of psyche's imaging, is as monotheistic as Freud was. Jung says that "in the place of a jealous God" Freud put sexuality that started to play "the role of a deus absconditus, a hidden or concealed god". Ironically for Jung "the psychological qualities of the two rationally commensurable opposites Yahweh and sexuality - remained the same, only the name was different" (Jung 1963, 151). But Jung alike put Self in place of God which is as jealous as Yahweh. Hillman on the contrary deprecates notion of psyche as "as ultimately a unity of self" (Hillman 1975, 41). In its polemics about the one and the multiple Jungian psychologies resembles theology. Jung himself says that "Monism, as a general psychological tendency" which endeavours to establish "one function or the other as the supreme psychological principle". Jung criticizes "psychological monism, or rather monotheism", as a simple but imperfect because it signifies "exclusion of the diversity and rich reality of life and the world" and permits "no real possibility of human development" (Jung 1969, 288). According to Jung, eventually pluralism must substitute monism: psychology "will have to recognize a plurality of principles and accommodate itself to them" (Jung 1969, 288-289). Ironically, both in theory and practice Jung introduces one function, Self, as the supreme psychological principle and relates it explicitly "with monotheism" (Jung 1969, 300). By contrast, psychology as revised by Hillman recognizes plurality of principles or rather, plurality of images:

"From the perspective of conservative, conventional Jungian psychology, Hillman is an idolater, not a Moses of the Self but an Aaron of images. He plays with and dances around the golden calves that the psyche continuously graves. Ultimately, Hillman matters because images matter-images that are concrete, particular, multiple, and different" (Adams 2006, 6).

\footnotetext{
2 Jungian theory is frequently explained and understood as based on the tension of opposites: Self - Ego, Conscious - Unconscious etc. For example, according to Lucy Huskinson "Jung maintains 'life is born only of the spark of opposites'. In accordance with the notion that 'there can be no reality without polarity', the psyche is construed by Jung as a living system of opposites" (Huskinson 2004, 35).
} 
One of the most significant kind of images are mythological images as if unconscious spoke in mythological language which is why some label unconscious as "mythological". Next part of this paper deals with this aspect of unconscious imagery.

\section{Mythological Unconscious: \\ Freud, Jung, Neumann, Hillman, Adams}

(...) basic to this modern view of persons is the psychology of Descartes; it imagines a universe divided into living subjects and dead objects. There is no space for anything intermediate, ambiguous, and metaphorical (Hillman 1975, 1).

Myths, dreams, and fantasies problematize existence - that is, they demonstrate just how problematic the attitudes of the ego are. They confront the ego and challenge it to respond heroically - (...), and then perhaps to integrate various alternative perspectives that a defensive ego may, in fact, regard as quite "unheroic" (Adams 2010, 49).

In the conventional course of philosophy lecturers frequently pay attention to the "opposition" between the myth and logos as an opposition or fundamental differrence in perspective. Usually it has following form:

LOGOS
Science
Rational knowledge
Reason
Literary truth
Philosophy
Expression through
conscious activity

\author{
MYTHOS \\ Mysticism \\ Intuitive knowledge \\ Imagination \\ Metaphorical truth \\ Mythology \\ Expression through manifestation of \\ the unconscious
}

Studying unconscious and its various ways of expression, we are challenged to go beyond such a polarity. This paper deals with image as a spontaneous product of unconscious which works as a mediator between the inner fantasy world and the world we perceive as reality. In this context I find important to recall Ackerknecht's note when thinking of ancient medicine men in primitive societies: for him medicine man "plays his role as the most irrational man in an irrational pattern" in contrast to modern physician who is "rationalizing even the irrational" (Ackerknecht 1942, 503-521). In my view image concept initiated by Jung and 
further extended by archetypal school suggests image as a mediator between "outer" and "inner" that not only relativizes objectivity of "inner" and "outer" but also old categories of logos and mythos because goes beyond them. For that matter, "going beyond" literal reading of "reality" is one of the basic principles of today's archetypal school:

"They are [archetypes] axiomatic, self-evident images to which psychic life and our
theories about it ever return. They are similar to other axiomatic first principles,
the models or paradigms, that we find in other fields. For 'matter', 'God', 'energy',
'life', 'health', 'society', 'art' are also fundamental metaphors, archetypes perhaps
themselves, which hold whole worlds together and yet can never be pointed to,
accounted for, or even adequately circumscribed" (Hillman 1975, xiii).

First, dynamic psychiatry, which was shaping slowly from the beginning of the 19th century, was mostly made of magnetizers and hypnotizers, and it did not result from activity of one person and had no rigid conceptual framework. Most of them viewed hypnosis as a via regia to unconscious. Situation started to change with French schools in Salpetriere and Nancy and especially with the link between psyche and myth in Freud.

The very correspondence between Freud and Jung is full of references to mythological imagery of human psyche. But already in 1897 in his letter to Wilhelm Fliess Freud mentions connection between psychology and mythology:

'Can you imagine what 'endopsychic myths' are? The latest product of my mental labour. The dim inner perception of one's own psychic apparatus stimulates thought illusions, which of course are projected onto the outside and, characterristically, into the future and the beyond. Immortality, retribution, the entire beyond are all reflections of our psychic internal [world]. Mechugge? Psychomythology" (Freud 1985, 286).

Yiddish word "mechugge" means "crazy" or "foolish". Did Freud mean his words about "endopsychic myths" seriously? Freud was convinced that human activity including the scientific one - is a "mythmaking": "The theory of the instincts is so to say our mythology" (...). Instincts are mythical entities, magnificent in their indefiniteness" (Freud 1964, 95). In his letter to Albert Einstein wrote: "It may perhaps seem to you as though our theories are a kind of mythology and, in the present case, not even an agreeable one. But does not every science come in the end to a kind of mythology like this? Cannot the same be said today of your own Physics?" (Freud 1964, 211).

For Freud mythology was a way of speaking about science and he, of course, exaggerated, but at the same time used classical mythology to confirm his psychoanalysis. It was especially case of Oedipus complex - endopsychic myth confir- 
ming existence of the complex, but also analysis confirming the myth. According to Freud Oedipus myth is universally - transculturally - valid and it is an endopsychic myth (close to what Jung called archetype), but did not understand unconscious as universal mythology (as Jung did):

"The idea that myth connotes a reality runs counter to the mainstream of modern Western thought, beginning with the rationalism of the seventeenth century, which has tended to equate the word 'myth' with 'fancy', meaning fallacy, delusion, or a mistaken notion, (...). The founders of psychoanalysis, Sigmund Freud and Carl Jung, thought that another form of discourse was called for to explain human behaviour (...). They turned to myth (...) - the Oedipal myth for Freud and universal mythology for Jung. With myth as primary tool, the psychoanalysis of human nature was first applied to the individual psyche and was then expanded to group psychology, including the analysis of culture and national character" (Schenk 2012, xiii-xiv).

According to Jung, Freud "discovered the first archetype, the Oedipus complex" [which] "is a mythological and a psychological motif simultaneously." But this myth describes "no more than a single archetype" whereas Jung believes that "there must be others" (Jung 1973, 525). Freud, however, anticipated existence of more comprehensive "endopsychological mythology" and Jung's theory according to which mythological images constitute "pictorial forms of the instincts": "The theory of the instincts is to say our mythology [...]. Instincts are mythical entities, magnificent in their indefiniteness" (Freud 1964, 20-25).

Post-Jungians revisited Oedipus myth in order to re-define and re-imagine psychoanalytical practice which led them to conceive psyche as multi-mythological, polytheist where different mythologies can coexist. It was already Kohut who declared that Laius-Oedipus relation exemplifies pathological relation between the father and the son whereas there are other myths (Odysseus and Telemachus for example) that emphasize possibility of their collaboration. Hillman's critique was even more radical:
"Hillman argues that if analysis were to employ other myths in addition to the Oedipus myth, many different myths with many different motifs - for example, Eros and Psyche ('love'), Zeus and Hera ('generativity and marriage'), Icarus and Daedalus ('flying and crafting'), Ares ('combat, anger, and destruction'), Pygmalion ('mimesis where art becomes life through desire'), Hermes, Aphrodite, Persephone, or Dionysus - then the methods of analysis would be very different and much truer to the diversity of human experience" (Adams 2008, 118).

Nevertheless, there are several common denominators: myth as a pictorial form of instinct and, consequently, necessity of inter-disciplinary training of analysts which should include not only biology, sexuology, and psychiatric symptomato- 
logy but also history of civilization, mythology, psychology of religion or the science of literature. Degree to which "mythic method" is applied varies. Even though Freud spoke of "endopsychic myths", he never established any "mythological school" within psychoanalysis as Jung who tended to interpret all images as of unmistakably mythological character. ${ }^{3}$

To interpret clinical material Jung used interpretative technique called "amplifycatory method" according to which he delineated parallel between clinic and mythological material. Something similar is findable in literature, particularly in James Joyce and T. S. Eliot. Eliot named Joyce as the one who used myth to use a parallel between contemporaneity and antiquity and like that moving beyond secular reality: "In using the myth, in manipulating a continuous parallel between contemporaneity and antiquity, Mr. Joyce is pursuing a method which others must pursue after him" (Eliot 1965, 679). In fact, Joyce applies the same method as Jung does except that for different purposes but for Adams "both modern psychology and modern literature employ mythological parallels in much the same way and to much the same effect" (Adams 2010, 36).

In fact, as a perspective "primacy of image" was introduced to different disciplines already in the first half of the 20th century. Jung's "heir apparent", Erich Neumann, constitutes excellent example of its application to interdisciplinary approach because his study of evolution of consciousness throughout history is based exclusively on mythical motifs to such a degree that - critically viewed by Giegerich in 1975 - is "completely oblivious to the historical" so when he speaks of "mythological (not culturo-historical) stages of development [he] stresses that stage here does not refer to any historical epoch, we might suppose that his actual intention was the representation of 'stages' within myth itself (as opposed to cultural history), of a sequence of mythical images in the sense of a background process to be located somehow 'above' history" (Giegerich 1975, 110-111).

The basic supposition of Neumann's experimental approach is so-called theory of recapitulation according to which ontogeny recapitulates phylogeny, a theory which can be found in Haeckel and again in Freud and Jung. Following Jung, Neumann adds a theory according to which the process of conscientization - both in individual and collective - can be charted on the basis of unconscious imagery. In case of cultural history such images are mythic images as we can find them in world religions. Analyzing such images (world parents, great mother, ouroboros etc.) leads to clear identification of archetypal stages in the evolution of consciousness in the history of mankind:

3 In this respect, Neumann was much more radical because he based his theories on mythological material without using clinical material. He is the example of one extreme whereas Michael Fordham is the example of another (no use of images or their mythological amplification). Such a onesidedness led to Giegerich's criticism. 
"An investigation of the archetypal stages also affords a better psychological orientation in a number of ancillary subjects, e.g., the history of religion, anthropology, folk psychology, and the like. All these can then be brought together on a psycho-evolutionary basis which would promote a deeper understanding. (...) these specialized sciences have not so far allowed themselves to be sufficiently enriched by depth psychology (...). (...) the psychological starting point of these disciplines emerges more and more plainly, and it is beginning to become obvious that the human psyche is the source of all cultural and religious phenomena" (Neumann 2014, xvii).

In his works Neumann developed basic Jung's premise of historically layered psyche whose basic components, i.e. archetypes "are like riverbeds which dry up when the water deserts them, but which it can find again at any time. An archetype is like an old watercourse along which the water of life has flown for centuries" (Jung 1963, 395). With these images-ideas Jung took up obsolete 19thcentury ethnopsychology (Lazarus, Steinthal, Wundt) ${ }^{4}$ and historiographical thought of Karl Lamprecht (1856-1915; Deutsche Geschichte, 1891-1909) for whom history was "nothing but applied psychology". After the World War II the same line of psycho-historical thought was taken up by Joseph A. Toynbee. ${ }^{5}$

In all above mentioned instances one can trace a way by which the concept of image slowly but systematically became the only source of meaning and truth already in 19th century not only in philosophy but also in psychology and arts. Limited extent of this paper does not allow examining all implications of the concept of the primacy of the image. However, all of them envisage image as a rediscovered, both mythological and archetypal source of meaning in (post-)secularized modern western culture. In this context I must mention almost automatic association of primacy of image within western epistemology with psychoanalysis. This paper refers to philosophical resources of primacy of image, but the truth is that the resources are much larger and include arts, aesthetics and literature or demarcation problem of Naturwissenschaften-Geisteswissenschaften. According to many, the spirit of psychoanalysis emerged from Goethe's and

\footnotetext{
4 This discipline was later, thanks to its cooperation with so-called völkisch movements, partly responsible for the psychological foundations of Nazi nationalism. See (Diriwächter 2004).

5 "As a historian, I can speak only for myself, to my mind, Jung has added a new dimension to history by opening up, for historians, an entry through which they can explore the subconscious depths of psyche. And he has, I believe, done more for history than that. The subconscious is a subterranean river from which the springs of all conscious activities draw their waters. The subconscious is thus the avenue to a comprehensive study of human nature and human affairs" (Toynbee 1956, 193).
} 
Schiller's aesthetics, from Goethe's Faust ${ }^{6}$ and especially from the late 18th-century concept of "inner nature" or romanticists' resistance (exemplified in Goethe's critique of Newton's Opticks, 1704, and in Farbenlehre, 1810) to mechanicist/materialist/determinist concept of nature so dear to the Enlightenment. Newly transformed epistemological status of image resulting from Kantian "transcendental turn" and Einbildungskraft was only a small instigation for later romanticist concepts that made image a primordial and ultimate source of meaning.

\section{References}

ACKERKNECHT, E. H. (1942): Problems of Primitive Medicine. In: Bulletin of the History of Medicine, 11(5), 503-521.

ADAMS, M. V. (2006): Hillman Alone in Pursuit of Imagination. Golden Calf Psychology. A paper presented at the "Psyche and Imagination" conference of the International Association for Jungian Studies at the University of Greenwich, London, July 8, 2006. Web. 3. Nov. 2017. $<$ http://www.jungnewyork.com/hillman_pursuit.shtml>

ADAMS, M. V. (2008): The Archetypal School. In: Young-Eisendrath, P. - Dawson, T. (org.): The Cambridge Companion to Jung, Cambridge: Cambridge University Press.

ADAMS, M. V. (2004): The Fantasy Principle. Imaginal Psychology and the Dethroning of 'Mr. Reality'. In: Fantasy Principle, Psychoanalysis of the Imagination. New York: Brunner-Routledge, 2-19.

ADAMS, M. V. (2010): The Mythological Unconscious. New York: Spring Publications, Putnam Conn.

DIRIWÄCHTER, R. (2004): Völkerpsychologie. The Synthesis That Never Was. In: Culture \& Psychology, 10(1): 85-109.

ELIOT, T. S. (1965). Myth and Literary Classicism. In: Ellman, R - Feidelson, C. (eds.): The Modern Tradition: Backgrounds of Modern Literature, New York: Oxford University Press.

FORDHAM, M. (1981): Neumann and Childhood. In: Journal of Analytical Psychology, 26, 99-122.

6 "(...) Goethe is said to have used with his friends a talking cure that in some respects resembled psychoanalysis, or in other words, he is seen to have been a proto-psychoanalyst; and second, Goethe's personality and works are seen as providing an ideal object for psychoanalysis, making him an exemplary neurotic and therefore an ideal analysand. (...) Goethe, especially in his first novel Die Leiden des jungen Werthers as well as in his great drama Faust, helped to create a 'culture of the unconscious' (...)" (Nicholls 2010, 91-92). 
FREUD, S. (1985): The Complete Letters of Sigmund Freud to Wilhelm Fliess, 18871904. Cambridge, Mass. and London: Belknap Press of Harvard University Press.

FREUD, S. (1964): New Introductory Lectures on Psycho-Analysis and Other Works. In: Standard Edition of the Complete Psychological Works of Sigmund Freud, vol. 22, Strachey, J. - Freud, A. - Strachey, A. - Tyson, A. (eds.). London: Hogarth Press.

GIEGERICH, W. (1975): Ontogeny = Phylogeny? A Fundamental Critique of Erich Neumann's Analytical Psychology. In: Spring, An Annual of Archetypal Psychology and Jungian Thought, 110-129.

GÖDE, G. (1999): Traditionslinien des "Unbewussten": Schopenhauer, Nietzsche, Freud, Tübingen: Discord.

HILLMAN, J. (1983): Inter-Views. Conversations with Laura Pozzo on Psychotherapy, Biography, Love, Soul, Dreams, Work, Imagination, and the State of Culture. New York: Colophon Books.

HILLMAN, J. (1975): Re-Visioning of Psychology. New York: Harper \& Row.

HUME, D. (1976): Treatise of Human Understanding. London: Oxford University Press.

HUSKINSON, L. (2004): Nietzsche and Jung: The Whole Self in the Union of Opposites. London: Brunner-Routledge.

JUNG, C. G. (1963): Memories, Dreams, Reflections. New York: Patheon Books. JUNG, C. G. (1969): Archetypes and the Collective Unconscious. In: The Collected Works of C. G. Jung (1953-1991), vol. 9, H. Read - M. Fordham - G. Adler - W. McGuire (eds.), trans. R. F. C. Hull, Princeton, NJ: Princeton University Press and London: Routledge.

JUNG, C. G. (1973): Experimental Researches. In: The Collected Works of C. G. Jung (1953-1991), vol. 2, H. Read - M. Fordham - G. Adler - W. McGuire (eds.), trans. R. F. C. Hull, Princeton, NJ: Princeton University Press and London: Routledge.

JUNG, C. G. (1970): Psychology and Religion: West and East. In: The Collected Works of C. G. Jung (1953-1991), vol. 11, H. Read - M. Fordham - G. Adler - W. McGuire (eds.), trans. R. F. C. Hull, Princeton, NJ: Princeton University Press and London: Routledge.

JUNG, C. G. (1971): Psychological Types. In: The Collected Works of C. G. Jung (1953-1991), vol. 6, H. Read - M. Fordham - G. Adler - W. McGuire (eds.), trans. R. F. C. Hull, Princeton, NJ: Princeton University Press and London: Routledge.

JUNG, C. G. (1969): Structure and Dynamics of Psyche. In: The Collected Works of C. G. Jung (1953-1991), vol. 8, H. Read - M. Fordham - G. Adler - W. McGuire (eds.), trans. R. F. C. Hull, Princeton, NJ: Princeton University Press and London: Routledge. 
JUNG, C. G. (1967): Two Essays on Analytical Psychology. In: The Collected Works of C. G. Jung (1953-1991), vol. 7, H. Read - M. Fordham - G. Adler - W. McGuire (eds.), trans. R. F. C. Hull, Princeton, NJ: Princeton University Press and London: Routledge.

JUNG, C. G. (1973): Letters: 1906-1950, ed. G. Adler, with A. Jaffé, trans. R.F.C. Hull, Princeton, N.J., Princeton University Press.

KUGLER, P. (2008): Psychic Imaging. A Bridge Between Subject and Object. In: Young-Eisendrath, P. - Dawson, T. (org.): The Cambridge Companion to Jung, Cambridge: Cambridge University Press.

MEYER, R. (2007): Clio's Circle. Entering the Imaginal World of Historians. New Orleans: Spring Journal Books.

NEUMANN, E. (2014): The Origins and History of Consciousness. Princeton: Princeton University Press.

NICHOLLS, A. (2010): The Scientific Unconscious: Goethe's Post-Kantian epistemology. In: Nicholls, A. - Liebscher, M. (eds.): Thinking the Unconscious. Nineteenth-Century German Thought, Cambridge: Cambridge University Press, 91-92.

SHELBURNE, W. A. (1988): Mythos and Logos in the Thought of Carl Jung. The Theory of Collective Unconscious in Scientific Perspective. New York: State University of New York Press.

SCHENK, R. (2012): American Soul. A Cultural Narrative. New Orleans: Spring Journal Books.

TOYNBEE, A. J. (1956): The Value of C. G. Jung's Work for Historian. In: Journal of Analytical Psychology, May 1(2), 193-194.

\section{Aleš Vrbata, PhD.}

State University of Feira de Santana

Literature and Cultural Diversity Post-Graduate Department

AVENIDA TRANSNORDESTINA S/N

Caixa Postal: $252-294$

CEP: 44.036-900

Feira de Santana

Brasil

alesvrbata@hotmail.com 